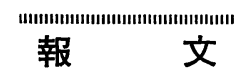

\title{
殺ダニ剤へキシチアゾクスの作物残留分析
}

時枝正則, 立花輝雄, 小林茂

五明健, 小野成男

日本曹達株式会社安全性研究所

(昭和 62 年 4 月 20 日受理)

\section{Residue Analysis of Acaricide Hexythiazox in Crops}

\author{
Masanori Tokieda, Teruo Tachibana, Shigeru Kobayashi, \\ Takeshi Gomyo and Shigeo ONO \\ Environmental Toxicology Laboratory, Nippon Soda Co., Ltd., \\ Takada, Odawara 250-02, Japan
}

\begin{abstract}
Two analytical methods of determining the residual amounts of hexythiazox [trans-5-(4chlorophenyl)-N-cyclohexyl-4-methyl-2-oxothiazolidine-3-carboxamide; HTZ] and its metabolites, PT-1-2, PT-cy-OH PT-cy-O in crops were investigated. One is the HTZ analytical method for HTZ only and the other the total method for HTZ and its metabolites. By the HTZ method, HTZ was extracted with methanol and purified through liquid-liquid separation and column chromatography, followed by HPLC determination. By the total method, HTZ and its metabolites were extracted with methanol and converted to a decyclohexylaminocarbonyl derivative (PT-1-3) through alkali hydrolysis, followed by column chromatography and HPLC determination. The detection limit by both methods was $0.01 \mathrm{ppm}$ and the fortified recovery was more than $80 \%$. Residue analyses of nine crops (12 matrices) suggested that there was no difference in residual amount between both methods. HTZ made up most of the residue in crops and its metabolites were negligible in amount. The results showed that the HTZ analytical method, which is simple and quick, is more suitable. GC was also effective in determining the residual amount of HTZ and its metabolites.
\end{abstract}

\begin{abstract}
緒 言
リンゴ，ナシ，柑橘類等の殺ダ二剤として使用されて いるニッソラン®の有効成分であるへキシチアゾクス [trans-5- (4-chlorophenyl) - $N$-cyclohexyl-4-methyl-2-oxothiazolidine-3-carboxamide, 以下 HTZ と記す] の安全性 評価の一環として，作物中での残留を把握することが必 要であった. 植物代謝研究の結果 ${ }^{1)}$ より, 作物中で HTZ はほとんど移行せず，比較的安定で大部分 HTZとして 残留しており, 少量の代謝物として脱シクロヘキシル体 (以下 PT-1-2 と記す), シクロヘキサン環の水酸化体 (以 下 PT-cy-OH と記す) およびシクロヘキサン環の酸化体 (以下 PT-cy-O と記す) が認められた。 そこで, HTZ 分
\end{abstract}

析法と上記代謝物をも対象にし，これらを脱シクロへキ シルアミノカルボニル体 (PT-1-3 と記す) に統一する 全分析法を高速液体クロマトグラフを用いて作成し, 種 種の作物について残留実態を検討した.

\section{分 析 法}

\section{HTZ 分析法}

1) 試薬および機器

試薬類は特級品をそのまま使用した。

$\mathrm{HTZ}$ 精製品: 融点 $108.0 \sim 108.5^{\circ} \mathrm{C}$, 白色結晶, 無臭 カラムクロマトグラフィー充填戍: 和光フロリジル PR $5 \%$ 含水させたもの

高速液体クロマトグラフ (HPLC)：島津 LC-3A 
同検出器：島津 SPD-2A

ホモジナイザー：キネマチカ社（スイ

ス）ポリトロン®

2) HPLC 条件

分離管：内径 $4.6 \mathrm{~mm}$, 長さ $25 \mathrm{~cm}$ のス テンレス製

充填戍: Zorbax ODS

移動相：アセトニトリルー水 $(7: 3, V)$

混液

流量： $1.0 \sim 1.5 \mathrm{ml} / \mathrm{min}$

カラム温度： $40^{\circ} \mathrm{C}$

検出条件：紫外線検出器, 波長 $225 \mathrm{~nm}$, 感度 0.04 AUFS

フローセル容量： $8.0 \mu \mathrm{l}$

記録紙速度： $5 \mathrm{~mm} / \mathrm{min}$

3）検量線の作成

$100 \mathrm{ppm}$ の HTZ アセトニトリル溶液を 調製し，これをアセトニトリルで希釈して $1.0 ， 2.5 ， 5.0$ および $7.5 \mathrm{ppm}$ の溶液を 調製する. 各溶液 $20 \mu \mathrm{l}$ をHPLC に注入す

る. HTZ の重量とピーク高さより検量線を作成する。

4）分析操作 [果実・野菜の場合]

(1) 抽出: 試料約 $500 \mathrm{~g}$ を約 $1 \mathrm{~cm}$ 角に細断し，その $50 \mathrm{~g}$ （ただし，ミカンおよびナッミカンの果皮は $25 \mathrm{~g}$ ) を称取し，メタノール $100 \mathrm{ml}$ を加えホモジナイザーで 3 分間磨研抽出する. スラリーを吸引濾過後, 容器およ び残渣をメタノール $50 \mathrm{ml}$ で洗い, 同様に濾過して濾液 を合わせる。

(2) 液液分配：この滤液に水 $100 \mathrm{ml}$ ，塩化ナトリウ 厶 $5 \mathrm{~g}$ を加光，へキサン $100 \mathrm{ml}$ で 2 回，それぞれ 5 分間 振とう抽出する。へキサン層を $0.01 \mathrm{~N}$ 水酸化ナトリウ 厶溶液 $100 \mathrm{ml}$ で 2 分間振とう洗浄し，水酸化ナトリウ ム層は捨てる、へキサン層を無水硫酸ナトリウム $5 \mathrm{~g}$ を 敷いた液相分離濾紙で脱水滤過する。 このへキサン溶液 にアセトニトリル $100 \mathrm{ml}$ を加党 5 分間振とう抽出する. この操作をもう一度繰り返す。アセトニトリル層を合わ せて濃縮乾固する.

(3) カラムクロマトグラフィー：上記濃縮残留物を ヘキサン $5 \mathrm{ml}$ に溶解し, あらかじめ $5 \%$ 含水フロリジ ル PR $10 \mathrm{~g}$ をへキサンを用いて充媜した内径 $1.2 \mathrm{~cm}$ の クロマト管中に加える. さらに， へキサン $5 \mathrm{ml}$ で容器 を洗い，クロマト管中に加える．溶出液は捨てる．へキ サン $90 \mathrm{ml}$, 次いで $1 \%$ アセトン/へキサン $100 \mathrm{ml}$ を流 し，溶出液は捨てる．さらに，同混合液 $150 \mathrm{ml}$ を流下し 溶出液を集め，溶出液を濃縮乾固する，その残留物をつ
セトニトリルで定容したのち, $20 \mu 1$ を前記条件の HPLC に注入しピーク高さを測定し，あらかじめ作成してある 検量線より HTZ の残留量を求める。

〔茶の場合〕

(1) 抽出: 試料約 $500 \mathrm{~g}$ をブレンダーでドライアイ スとともに粉砕後，その $10 \mathrm{~g}$ を秤取し，70\% アセトン 溶液 $100 \mathrm{ml}$ を加えホモジナイザーで 3 分間磨䂶抽出し たのち， 30 分間振とう抽出する． スラリ一を吸引濾過 後, 容器および残渣を $70 \%$ アセトン溶液 $100 \mathrm{ml}$ で洗い, 同様に濾過して濾液を合わせる. 以下の操作は果実・野 菜の場合と同じである.

Fig. 2 に分析法の概要を示す.

\section{2. 全分析法}

1) 試薬および機器

試薬類はすべて特級品をそのまま使用した。ただし， カラムクロマトグラフィーに使用したジクロロメタンに はメタノールを $0.5 \%$ 添加した。

PT-1-3 精製品：融点 $146^{\circ} \mathrm{C}$, 白色結晶, 無臭 カラムクロマトグラフィーの充壃浏：アルミナ（メ ルク 1077 中性, 活性度 1 ）、に 10\% 含水させたもの パックドカラム：日本ウォーターズ社セップパック $\mathrm{C}_{18}$

HPLC および検出器： HTZ 法に同じである.

2) HPLC 条件

移動相：アセトニトリル-水 $(4: 6, \mathrm{~V})$ 混液 


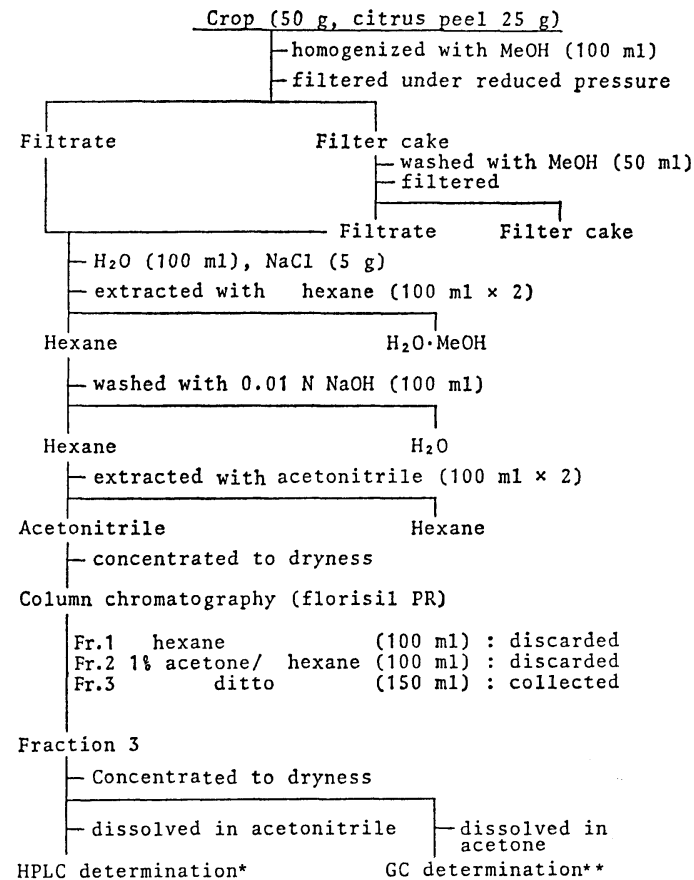

Fig. 2 Flow diagram of an analytical method for HTZ residues in crops (HTZ method).

Operating conditions of HPLC and GC. *Column: Zorbax ODS $\phi 4.6 \mathrm{~mm} \times 250 \mathrm{~mm}$, detector: UV $(225 \mathrm{~nm})$, mobile phase: $70 \%$ acetonitrile, flow rate: $1.0 \sim 1.5 \mathrm{ml} / \mathrm{min}$, temp.: $40^{\circ} \mathrm{C}$. ${ }^{* *}$ Column: $5 \%$ PEG-HT/Uniport HP (60 80 mesh) $\phi 3$ $\mathrm{mm} \times 500 \mathrm{~mm}$, detector: FTD, gas: carrier gas (He) $50 \mathrm{ml} / \mathrm{min}, \mathrm{H}_{2} 4.0 \mathrm{ml} / \mathrm{min}$, air $200 \mathrm{ml} / \mathrm{min}$, temp.: inject, detector $250^{\circ} \mathrm{C}$, column $240^{\circ} \mathrm{C}$.

\section{流量: $1.5 \mathrm{ml} / \mathrm{min}$}

他条件：HTZ 法に同じである.

3）検量線の作成

100 ppm の PT-1-3 アセトニトリル溶液を調製し，こ の溶液をアセトニトリルで希釈し，1.0，2.5 および 5.0 ppm 溶液を調製する，各溶液 $20 \mu \mathrm{l}$ を高速液体クロマト グラフに注入する. PT-1-3 の重量とピーク高さより検 量線を作成する.

4）分析操作〔果実・野菜の場合〕

(1) 抽出：試料約 $500 \mathrm{~g}$ を約 $1 \mathrm{~cm}$ 角に細断し，その $50 \mathrm{~g}$ を科取したのち，メタノール $100 \mathrm{ml}$ を加えホモジ ナイザーで 3 分間磨砕抽出する. スラリーを吸引濾過

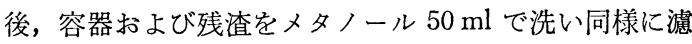
過して濾液を合わせる。

(2) 液液分配：この濾液に水 $100 \mathrm{ml}$, 塩化ナトリウ 厶 $10 \mathrm{~g}$ を加え, 塩酸で $\mathrm{pH} 3$ に調整したのち, ジクロロ
メタン $100 \mathrm{ml}$ で 2 回，それぞれ 5 分間振とう抽出する. ジクロロメタンを合わせ, 水 $100 \mathrm{ml}$ を加え 2 分間振とう して洗浄する. ジクロロメタン層を一旦, 別の容器に移 したのち, 水層に新しいジクロロメタン $100 \mathrm{ml}$ を加え 5 分間振とう抽出し, ジクロロメタン層は先に分取したジ クロロメタン層に合わせ, 無水硫酸ナトリウム $5 \mathrm{~g}$ を敷 いた液相分離濾紙で脱水後，濃縮乾固する。

(3) 液液分配：濃縮乾固物をへキサン $100 \mathrm{ml}$ で分液 漏斗に移し, アセトニトリル $100 \mathrm{ml}$ で 2 回, それぞれ 5 分間振とう抽出する. アセトニトリル層を合わせて濃 縮乾固する.

(4) 加水分解: 乾固物にメタノール $5 \mathrm{ml}$ 安加えて溶 解し $0.01 \mathrm{~N}$ 水酸化ナトリウム溶液 $50 \mathrm{ml}$ を加え, 還流 冷却管を付けマントルヒーターを用いて, 20 分間加熱還 流する. 反応後, 室温まで冷却し, 冷却管内部をメタノ ール $50 \mathrm{ml}$ で洗い反応液に合わせる.この内容物を 300 $\mathrm{ml}$ の分液漏斗中に移し, 塩化ナトリウム $5 \mathrm{~g}$ を溶解した のち, ヘキサン $100 \mathrm{ml}$ を加え 2 分間振とう洗浄する. $50 \%$ メタノール溶液を一旦, 別の容器に移し, 一キサン 層に新しい $50 \%$ メタノール溶液 $100 \mathrm{ml}$ を加え，5分間 振とうし，逆抽出する.この $50 \%$ メタノール溶液を先 に分取した $50 \%$ メタノール溶液に合わせる。、キサン 層は捨てる．合わせた $50 \%$ メタノール溶液をジクロロ メタン $100 \mathrm{ml}$ で 2 回とれぞれ 5 分間振とう抽出する. $50 \%$ メタノール溶液は捨てる. ジクロロメタン層を無水 硫酸ナトリウム $5 \mathrm{~g}$ を敷いた液相分離濾紙で脱水濾過し 濃縮乾固する.

(5) カラムクロマトグラフィー：濃縮物を $10 \%$ ジク ロロメタン/ヘキサン $5 \mathrm{ml}$ で溶解し，その中へカラムク ロマトグラフィー用充填剂 $1 \mathrm{~g}$ を加え軽く攪汼し, 10 分 間静置する．あらかじめ上記充埧剤 $4 \mathrm{~g}$ をへキサンを用 いて充填した内径 $1.2 \mathrm{~cm}$ のクロマト管に上記混合物を 流し入れ, 流出液は捨てる. 同混合液 $5 \mathrm{ml}$ で容器を洗い クロマト管中に加え, 続いて同混合液 $90 \mathrm{ml}$ を流下し, さらに $20 \%$ 塩化メチンン/へキサン $100 \mathrm{ml}$ を流下し て, 流出液は捨てる. 次に同混合溶液 $100 \mathrm{ml}$ で PT-1-3 を溶出させ, 溶出液を減圧下で濃縮乾固する.残留物をア セトニトリルで定容したのち, $20 \mu l$ を前記条件の HPLC に注入し，ピーク高さを測定し，あらかじめ作成してあ る検量線より PT-1-3 の量を求め, HTZ としての残留量 に換算する.

〔ミカンおよびナツミカン果皮の場合：試料科取量 $25 \mathrm{~g}]$

上記(5)で最終的に得られた乾固物を $10 \%$ メタノール 溶液 $10 \mathrm{ml}$ で溶解し, あらかじめメタノール $5 \mathrm{ml}$, 水 
$10 \mathrm{ml}$ で洗浄したパックドカラムに加光, 流出液は捨て る.続いて $50 \%$ メタノール溶液 $12 \mathrm{ml}$ で PT-1-3 を溶出 させ, 溶出液を濃縮乾固し，アセトニトリルで定容後, HPLC に注入する. あらかじめ作成してある検量線から PT-1-3 の量を求め, HTZ としての残留量に換算する.

[茶の場合： 試料秤取量 $5 \mathrm{~g}$ ]

(1) 抽出: HTZ 法の抽出に同じである.

(2) 液液分配：濾液に水 $100 \mathrm{ml}$, 塩化ナトリウム $10 \mathrm{~g}$ を加光, 塩酸で $\mathrm{pH} 3$ に調整したのち, ジクロロメタン $100 \mathrm{ml}$ で 2 回, それぞれ 5 分間振とう抽出する. ジクロ ロメタン層を合わせ, $0.01 \mathrm{~N}$ 水酸化ナトリウム溶液 100 $\mathrm{ml}$ を加え 1 分間振とうし洗浄する. ジクロロメタン層 を一旦別の容器に移したのち，アルカリ層に新しいジク ロロメタン $100 \mathrm{ml}$ を加え 5 分間振とう抽出し, 先のジク ロロメタンに合わせる，無水硫酸ナトリウム $5 \mathrm{~g}$ を敷い た液相分離滤紙で脱水後，濃縮乾固する。

(3) 加水分解： 果実・野菜の場合に同じである. た だし加水分解には， $0.02 \mathrm{~N}$ 水酸化ナトリウム溶液 $50 \mathrm{ml}$ を用いる。

(4) 液液分配は 4)(3に同じである.

(5) カラムクロマトグラフィー：濃縮乾固物を水 10 $\mathrm{ml}$ に溶解し,あらかじめメタノール $5 \mathrm{ml}$ 打よび水 $10 \mathrm{ml}$ で洗浄したパックドカラムに通し，流出液は捨てる，さ らに, 水 $10 \mathrm{ml}$ で容器を洗い, 続いて $10 \%$ メタノール 溶液 $10 \mathrm{ml}$ で容器を洗浄して，それぞれパックドカラム に流し流出液は捨てる。続いて $50 \%$ メタノール溶液 10 $\mathrm{ml}$ で容器を洗浄後, パックドカラムに流し PT-1-3 を溶 出させる．溶出液を捕集し，50\% メタノール溶液 $40 \mathrm{ml}$ を加え $50 \mathrm{ml}$ のジクロロメタンで 2 回，それぞれ 5 分間 振とう抽出する．ジクロロメタン層を無水硫酸ナトリウ ムを敷いた液相分離滤紙で滤過したのち，濃縮乾固する。 濃縮物を $10 \%$ ジクロロメタン/ヘキサン $5 \mathrm{ml}$ で溶解 し，その中へカラムクロマトグラフィー用充填威 $1 \mathrm{~g}$ を 加光軽く㨨拌し， 10 分間静置する. あらかじめへキサン で上記充㙗戍 $4 \mathrm{~g}$ をつめたクロマト管に上記混合物を流 し入れ，溶出液は捨てる. 同混合液 $5 \mathrm{ml}$ で容器を洗い, クロマト管中に加え, 続いて同混合液 $90 \mathrm{ml}$ を流し，さ らに， $20 \%$ ジクロロメタン/ヘキサン $100 \mathrm{ml}$ を流下し て流出液は捨てる. 次に同混合液 $100 \mathrm{ml}$ で PT-1-3 を溶 出させ, 溶出液を減圧下で濃縮乾固する. 残留物を了七 トニトリルで定容後, $20 \mu \mathrm{l}$ を前記条件の HPLC に注入 しピーク高さを測定し，あらかじめ作成してある検量線 より PT-1-3 の量を求め, HTZ としての残留量に換算 する.

Fig. 3 に分析法の概要を示す.

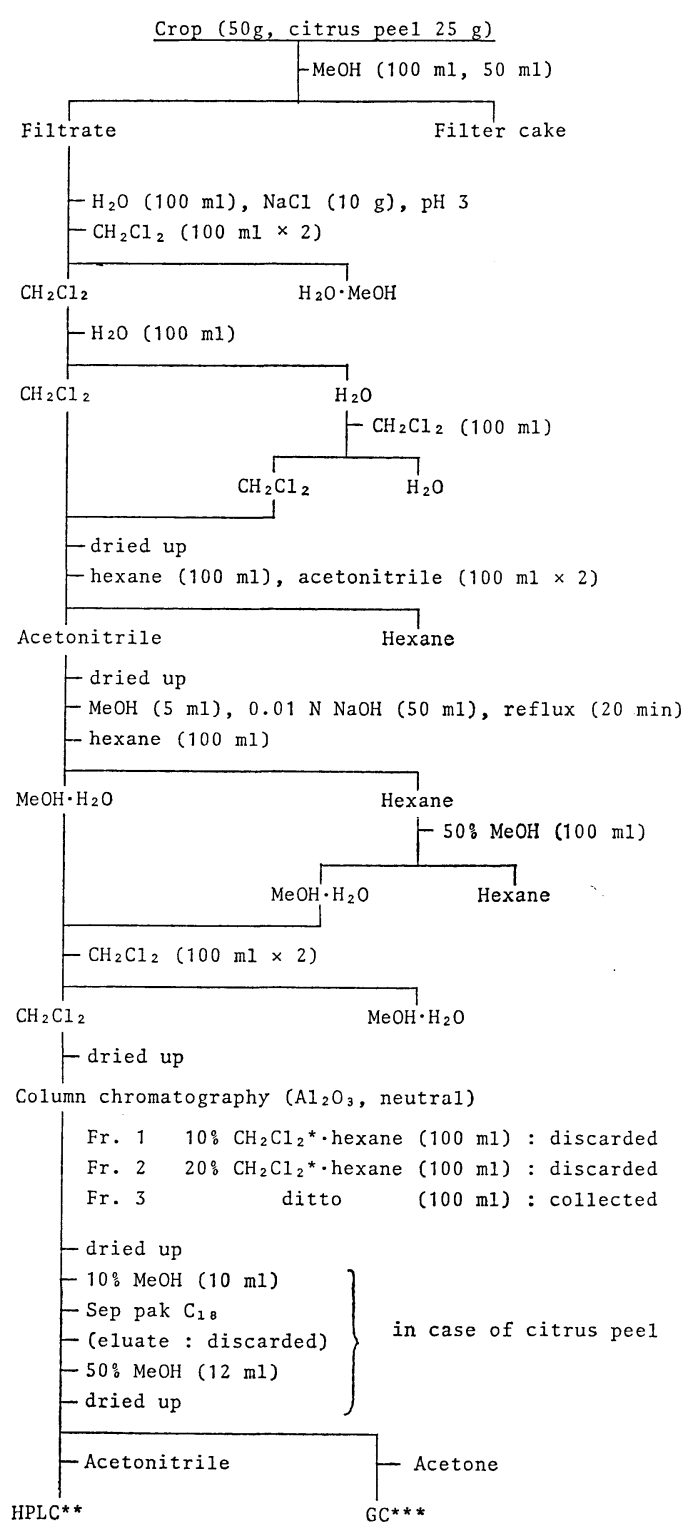

Fig. 3 Flow diagram of an analytical method for HTZ and its metabolites in crops (Total method).

*Contains $0.5 \% \mathrm{MeOH}$. Operating conditions of HPLC and GC. ${ }^{* *}$ Mobile phase: $40 \%$ acetonitrile, flow rate: $1.5 \mathrm{ml} / \mathrm{min}$, other conditions: much the same as HTZ method. ${ }^{* * *}$ Much the same as HTZ method.

実
1. HTZ 法の検討
1）抽出溶媒の検討
作物からの抽出溶媒としてメタノールを使用した.


タノールの代わりにアセトンについても検討したが，と くにすぐれた利点はなく，むしろアセトンのほうが作物 成分を多量に抽出し，クリンアップが煩雑になる場合が あった. しかし, 茶からの抽出については, メタノール, アセトン, 含水アセトン, 含水メタノールについて比較 した結果，含水アセトン溶液を用いた場合，最も HTZ の抽出率がよかったので採用した. また, 溶媒抽出前の製 茶の均質化にはドライアイスを用いると良好であった。

2) クリンアップの検討

液液分配とカラムクロマトグラフィーによるクリンフ ップを検討した. HTZを $50 \%$ メタノール溶液とーキサ ンまたはジクロロメタンで分配した場合，HTZ はいず れの溶媒にも分配されることがわかったが，ジクロロメ タンを用いた場合, 妨害物をより多く抽出するため HTZ の抽出にはへキサンを採用した，へキサン中の HTZ は 希水酸化ナトリウム溶液 $(0.1,0.01 \mathrm{~N})$ には移行しな いことからアルカリ洗浄をクリンアップ操作に入れた. また， ヘキサンとアセトニトリルの分配では HTZ がア セトニトリルに分配されることがわかったので，へキサ ン中の HTZ の抽出にアセトニトリルを用いた.

カラムクロマトグラフィーの検討は, フロリジル（和 光, $60 \sim 100$ メッシュ), フロリジル $\mathrm{PR}$, 中性アルミナ (メルク 1077, 活性度 1 ) の 3 種類の充塤剤と, 4 種類の 溶媒系，1\% および $3 \%$ アセトン/へキサン，1\%およ び $10 \%$ ジクロロメタン $(0.5 \%$ メタノール含有 $) / へ キ$ サンの組合せで行なった. その結果, いずれの組合せで も HTZ は溶出したが，妨害物との分離において前記分 析操作中に示した条件が最もよかった.

\section{3) HPLC の条件検討}

$\mathrm{HTZ}$ はアセトニトリル溶液中で極大吸収波長は短波 長領域の $225 \mathrm{~nm}$ 付近にあるが, 分子吸光係数は約 $2 \times$ $10^{4}$ であり, 紫外線検出器付 HPLC での定量が可能であ った. 充塡剤として吸着型のZorbax SILを用いた場合 は，作物によってはその由来成分と HTZ の分離が良好 でない場合もあった，他方，Zorbax ODSを用いる場合 は, 移動相としてアセトニトリル・水, アセトニトリル・ 緩衝液, メタノール・水, メタノール・緩衝液の溶媒系 について検討した. 緩衝液は $\mathrm{pH} 5$ (酢酸ナトリウム-酢
酸系) と $\mathrm{pH} 7$ (リン酸二水素カリウムーリン酸水素二ナ トリウム系）の 2 種類を用いた. その結果, いずれの移 動相でも作物由来の成分と HTZ が良好に分離した. ピ ーク形状はいずれも定量には十分であったが，アセトニ トリル系のほうが若千メタノール系より良好であった。 また, カラム保守の点から緩衝液より水を混合させたほ うが便利であった。このため, 充填戍としてZorbax ODS, 移動相としてアセトニトリル・水系を採用した.

4）検出限界および添加回収試験

HTZ $5 \mathrm{ng}$ を注入した時, 約 $5 \mathrm{~mm}$ の明瞭なピークが 認められたので，これを最小検出量とした。試料科取量 を $50 \mathrm{~g}$, 最終液量を $2 \mathrm{ml}$, 注入量 $20 \mu \mathrm{l}$ とした場合, 検 出限界は $0.01 \mathrm{ppm}$ となる. 各種作物に HTZを添加し て前記分析法に従い分析 $(n=2)$ し, 回収率を求めた結 果 (Table 1) 平均回収率は $89.2 \%$ であった. リンゴに 0.05 ppm 濃度で HTZ を添加し, 5 回の繰り返し分析を 行ない, 変動係数 (c.v.) を算出した結果 (Table 2), $3.0 \%$ であった. これらの值から本分析法が十分に実用

Table 1 Recoveries of $\mathrm{HTZ}$ in crops by $\mathrm{HTZ}$ method (HPLC).

\begin{tabular}{lccc}
\hline \multicolumn{1}{c}{ Crops } & $\begin{array}{c}\text { Sample } \\
\text { weight } \\
(\mathrm{g})\end{array}$ & $\begin{array}{c}\text { HTZ } \\
\text { added } \\
(\mu \mathrm{g})\end{array}$ & $\begin{array}{c}\text { Recov- } \\
\left.\text { ery }(\%)^{\mathrm{a}}\right)\end{array}$ \\
\hline Grape & 50 & 2.5 & 82.8 \\
$\begin{array}{l}\text { Satsuma mandarin } \\
\text { (pulp) }\end{array}$ & 50 & 2.5 & 88.6 \\
$\quad$ (peel) & 25 & 1.25 & 95.7 \\
Cucumber & 50 & 2.5 & 89.3 \\
Summer orange & & & \\
$\quad$ (pulp) & 50 & 2.5 & 90.4 \\
$\quad$ (peel) & 25 & 1.25 & 93.8 \\
Green pepper & 50 & 2.5 & 87.1 \\
Peach & & & \\
$\quad$ (pulp) & 50 & 2.5 & 88.9 \\
$\quad$ (peel) & 25 & 1.25 & 90.2 \\
Green tea & 10 & 1.25 & 84.4 \\
Strawberry & 50 & 2.5 & 89.8 \\
\hline
\end{tabular}

a) Figures are the average of duplicates.

Table 2 Coefficient of variation by HTZ method (HPLC).

\begin{tabular}{cccccc}
\hline Crop & $\begin{array}{c}\text { Sample weight } \\
(\mathrm{g})\end{array}$ & $\begin{array}{c}\text { HTZ added } \\
(\mu \mathrm{g})\end{array}$ & $\begin{array}{c}\text { Recovery } \\
(\%)\end{array}$ & $\begin{array}{c}\text { Average } \\
(\%)\end{array}$ & $\begin{array}{c}\text { c.v. } \\
(\%)\end{array}$ \\
\hline \multirow{2}{*}{ Apple } & 50 & 2.5 & $\begin{array}{l}89.3,89.7,91.8 \\
92.8,96.2\end{array}$ & 92.0 & 3.0 \\
& & & & & \\
\hline
\end{tabular}


性のあることがわかった。

\section{2. 全分析法の検討}

1) 統一条件の検討

HTZ および代謝物を一つの化合物に統一して定量す ることを検討した. 加水分解実験の結果より, HTZ は 中性, 酸性溶液中では安定であるが, アルカリ溶液中で は比較的分解が速く, 主生成物は PT-1-3 であったので, $\mathrm{HTZ}$ および代謝物を PT-1-3 に定量的に変換する条件 を検討した. 3 濃度の水酸化ナトリウム溶液中に各化合 物を別々に添加し，20 分間加熱還流した。 その結果， pH 12 では HTZ および代謝物は定量的に PT-1-3 に变 換され，PT-1-3 は安定に残存することがわかったので， 本条件を採用した。 pH 13 では生成した PT-1-3 の安定 性が悪く, また, $\mathrm{pH} 11$ では加水分解が不十分で $\mathrm{HTZ}$ 等 が残存していた。

2) 抽出条件の検討

HTZ 法に同じである.

\section{3） クリンアップの検討}

液液分配およびカラムクロマトグラフィーによるクリ ンアップを検討した. PT-1-2, PT-1-3, PT-cy-OH, PTcy-O 等を $50 \%$ メタノール溶液とへキサンまたはジクロ ロメタンで分配した場合，これらの化合物はへキサンに 十分分配されなかったが (20\% 以下)，ジクロロメタン には定量的に分配された. PT-cy-OH の抱合体は 50\% メタノール溶液を酸性にすることによりジクロロメタン に定量的に分配されたので，50\%メタノール抽出溶液 を $\mathrm{pH} 3$ に調整し，転溶溶媒にはジクロロメタンを用い た. 茶の場合は，このジクロロメタン層にタンニン類が 多く抽出されたが， $0.01 \mathrm{~N}$ 水酸化ナトリウム溶液で洗 浄すると除去効果が認められた. HTZ, PT-1-2, PT-1-3, PT-cy-OH, PT-cy-O のアルカリ溶液への移行はほとえ ど認められなかった。ささらに，へキサンとアセトニトリ ルの分配において HTZ および上記代謝物はアセトニト リルに分配されることがわかったので，へキサンからの 抽出にアセトニトリルを用いた。

カラムクロマトグラフィーの検討には充填剤としてフ ロリジル（和光 60〜100メッシュ）および中性アルミ ナを用い，移動相としてフロリジルにはフセトン・へキ サン系, アルミナにはジクロロメタン・へキサン系を用 いた．その結果，妨害物との分離においてアルミナのほ うがすぐれており，前記分析法に示した条件を採用した。

柑橘類の果皮や茶等, 妨害物の多い作物は液液分配と 通常のカラムクリンアップのみでは精製が不十分であっ た. そのため, 逆相系のパックドカラムを用いて,さら にクリンアップの検討をした，茶の場合，タンニン類の
除去が不十分であると, カラムクロマトグラフィーによ る精製時にカラム表面の目づまりや PT-1-3 溶出分画が ずれる現象がみられたが，カラムクロマトグラフィーを 行なう前にパックドカラムを用いることにより, タンニ ン類と PT-1-3 の分離が良好であった，柑橘果皮由来の 妨害成分の除去も, 液液分配とカラムクロマトグラフィ 一では不十分であったので, さらに逆相系パックドカラ ムによるクリンアップを検討した，その結果，妨害成分 はパックドカラムに残存し PT-1-3 が溶出したため良好 なクリンアップができた.

4) HPLC 条件の検討

PT-1-3 は HTZ と同様にアセトニトリル中で極大吸 収波長は短波長領域の $225 \mathrm{~nm}$ 付近にあるが，分子吸光 係数は約 $2 \times 10^{4}$ であり, 紫外線検出器付 HPLC での定 量が可能であった. そこで，HTZ と同様に検討を行な い，前記分析法中に記載した条件を採用した。

5）検出限界および添加回収試験

PT-1-3 を $3 \mathrm{ng}$ 注入した時 (HTZ 換算で $5 \mathrm{ng}$ ), 高さ 約 $4 \mathrm{~mm}$ の明瞭なピークが認められたので，これを最小 検出量とした. 試料科取量を $50 \mathrm{~g}$, 最終液量を $2 \mathrm{ml}$, 注 入量を $20 \mu \mathrm{l}$ とした場合，検出限界は HTZ 換算で 0.01 ppm となる. 各種作物に HTZ および代謝物を添加して 分析 $(n=2)$ し, 回収率を求めた結果 (Table 3), 平均回 収率は 83.5\% であった. リンゴに $0.05 \mathrm{ppm}$ 濃度で $\mathrm{HTZ}$ を添加し, 5 回の繰り返し分析を行ない, 変動係数 (c.v.) を算出した結果 (Table 4)，2.3\% であった.これらの 值から，本分析法が十分に実用性のあることがわかった。

\section{3. ガスクロマトグラフィーの検討}

$\mathrm{HTZ}$ は, アルカリ加水分解あるいは GC 中で PT-1-3 に変換されることがわかった．このため HTZ 法および 全分析法ともに GC で分析を行なう場合は，PT-1-3 と して定量することになる．PT-1-3 は硫黄原子や窒素原 子を有しているため, 電子捕獲検出器 (ECD) のほかに, 熱イオン検出器 (FTD), 炎光光度検出器 (FPD) を用 いて種々の充填剤との組合せで検出条件の検討を行なっ た. HTZ 法の場合, ピーク形状と最小検出量より, 検 出器としてはFTD が, 充填剤としては PEG-HT/Uniport HP が最良であった． PEG-HT 系では，HTZ がほ ぼ定量的に PT-1-3 に変換され，GC 定量に何ら問題は なかった. OV-17/Chromosorb W は最小検出量が PEGHT 系より劣り，検出限界が HPLC に比べて不十分で あった。他方, 全分析法の場合は PT-1-3 に変換後, GC に注入するので，GC 中で HTZ および代謝物が PT-1-3 に定量的に変換される必要はないので，上記 2 種類の充 顚剤のほかに DC-200, SE-30 等についても検討したが, 
Table 3 Recoveries of each fortified compound in crops by total method (HPLC).

\begin{tabular}{|c|c|c|c|c|c|c|c|}
\hline \multirow{2}{*}{ Crops } & \multirow{2}{*}{$\begin{array}{l}\text { Sample } \\
\text { weight } \\
\text { (g) }\end{array}$} & \multirow{2}{*}{$\begin{array}{l}\text { Amount } \\
\text { added } \\
(\mu \mathrm{g})\end{array}$} & \multicolumn{5}{|c|}{ Recovery $(\%)^{a)}$} \\
\hline & & & HTZ & PT-1-2 & PT-1-3 & $\begin{array}{l}\text { PT-cy- } \\
\mathrm{OH}^{\mathrm{b})}\end{array}$ & $\begin{array}{c}\text { PT-cy- } \\
\mathrm{O}^{\text {b) }}\end{array}$ \\
\hline Apple & 50 & 2.5 & 90.0 & 81.8 & 84.2 & 86.2 & 82.8 \\
\hline Grape & 50 & 2.5 & 90.4 & 88.4 & 83.8 & 88.4 & 85.8 \\
\hline \multicolumn{8}{|c|}{ Satsuma mandarin } \\
\hline (pulp) & 50 & 2.5 & 83.7 & 83.7 & 83.0 & 78.8 & 83.6 \\
\hline (peel) & 25 & 1.25 & 81.3 & 74.4 & 82.0 & 77.9 & 82.0 \\
\hline Cucumber & 50 & 2.5 & 93.0 & 85.8 & 91.8 & 86.0 & 85.8 \\
\hline \multicolumn{8}{|c|}{ Summer orange } \\
\hline (pulp) & 50 & 2.5 & 84.0 & 86.8 & 88.2 & 81.8 & 83.7 \\
\hline (peel) & 25 & 1.25 & 83.6 & 80.7 & 88.9 & 81.0 & 81.8 \\
\hline Strawberry & 50 & 2.5 & 84.0 & 83.0 & 88.0 & 82.8 & 83.6 \\
\hline Green tea & 5 & 1.25 & 75.2 & 77.2 & 81.8 & 76.4 & 76.4 \\
\hline
\end{tabular}

a) Figures are the average of duplicates.

b) 4-OH and 4-oxo compounds in Fig. 1 were used as representatives.

Table 4 Coefficient of variation by total method (HPLC).

\begin{tabular}{|c|c|c|c|c|c|c|}
\hline \multirow{2}{*}{ Crop } & \multirow{2}{*}{$\begin{array}{l}\text { Sample } \\
\text { weight } \\
\text { (g) }\end{array}$} & \multicolumn{2}{|c|}{ Compound added } & \multirow{2}{*}{$\begin{array}{l}\text { Recovery } \\
(\%)\end{array}$} & \multirow{2}{*}{$\begin{array}{l}\text { Average } \\
(\%)\end{array}$} & \multirow{2}{*}{$\begin{array}{l}\text { c.v. } \\
(\%)\end{array}$} \\
\hline & & Name & Amount $(\mu \mathrm{g})$ & & & \\
\hline Apple & 50 & $\mathrm{HTZ}$ & 2.5 & $\begin{array}{l}85.7,88.3,89.8 \\
90.2,90.8\end{array}$ & 89.0 & 2.3 \\
\hline
\end{tabular}
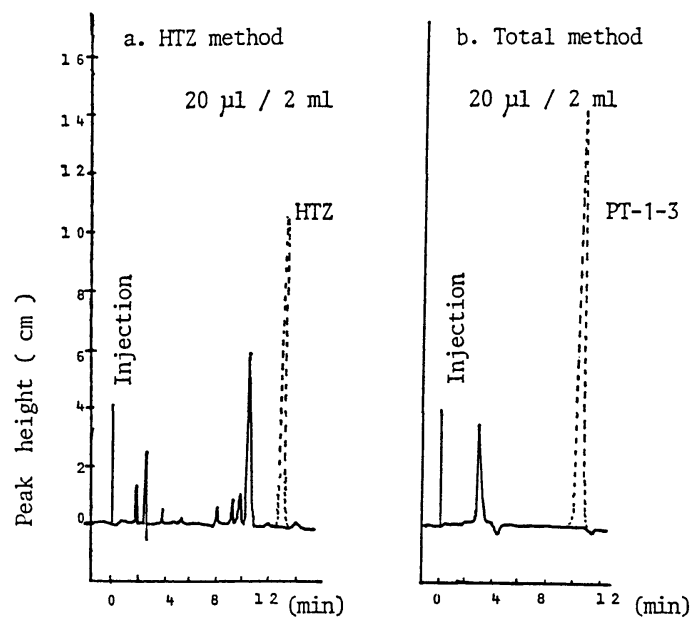

Fig. 4 Examples of HPLC chromatograms for control apples.

Dotted lines show the position of HTZ (100 ng) and PT-1-3 (100 ng).

十分な最小検出量が得られず，HTZ 法と同様に PEGHT 系を使用する必要があった。そこで検出器は FTD, 充填刜は PEG-HT/Uniport HP の組合せで HTZ 法およ び全分析法で $0.05 \mathrm{ppm}$ の添加回収試験をリンゴ，ナッ
ミカン果皮を用いて行なった結果, 回収率は 80 90\% と 良好であった.しかし全分析法で茶の分析を行なう時は， HPLC 法よりさらに長い精製工程が必要であった.

\section{4. 残留分析}

各地の農業試験場等でニッソラン水和剤（ヘキシチア ゾクス $10 \%$ 含有）を散布した. リンゴ，キュウリ，イチ ゴ, ナッミカン, ミカン, ブドウ，モモ，およびニッソ ランV乳刋（へキシチアゾクス $5 \%$ 含有）を散布したピ ーマンおよび茶をHPLCを用いて HTZ 法と全分析法 で分析した (Table 5). この結果, 残留量は柑滳の果皮 では $0.16 \sim 1.21 \mathrm{ppm}$, 果肉では検出限界以下, リンゴ, イチゴでは $0.5 \mathrm{ppm}$ 以下であった。 また，茶の場合， 7 日後では約 $10 \mathrm{ppm}$ 程度の残留が認められたが, 経時的 に減少していった.

\section{考察}

ニッソラン水和剤を戋場で散布し，収穫した作物中の 残留実態を確認するため, 親化合物のほか, 代謝物につ いての残留分析法も検討した. HTZ の植物代謝研究の 結果から，作物中で HTZ は比較的安定で大部分が HTZ で残留しており, 少量の代謝物として PT-1-2, PT-cy$\mathrm{OH}, \mathrm{PT}-\mathrm{cy}-\mathrm{O}$ 等が認められた1). ミカン果皮中では PT. 
Table 5 Crop application history and residue amount of $\mathrm{HTZ}$ and its metabolites by HTZ method and total method (HPLC).

\begin{tabular}{|c|c|c|c|c|c|c|}
\hline \multirow{2}{*}{ Crop } & \multirow{2}{*}{ Location } & \multirow{2}{*}{$\begin{array}{l}\text { Dosage } \\
(\mathrm{L} / 10 \mathrm{a})\end{array}$} & \multirow{2}{*}{$\begin{array}{c}\text { Number } \\
\text { of } \\
\text { application }\end{array}$} & \multirow{2}{*}{$\begin{array}{l}\text { Days after } \\
\text { last } \\
\text { application }\end{array}$} & \multicolumn{2}{|c|}{ Residues (ppm) a) } \\
\hline & & & & & HTZ & Total $^{\text {b) }}$ \\
\hline Apple & Toyama & $\begin{array}{l}10 \% \mathrm{WP} \\
\times 2000 \\
600 \mathrm{~L}\end{array}$ & $\begin{array}{l}1 \\
1 \\
1\end{array}$ & $\begin{array}{r}7 \\
14 \\
30\end{array}$ & $\begin{array}{l}0.22 \\
0.13 \\
0.04\end{array}$ & $\begin{array}{l}0.25 \\
0.12 \\
0.05\end{array}$ \\
\hline Cucumber & Kochi & $\begin{array}{l}10 \% \mathrm{WP} \\
\times 2000 \\
220+350 \mathrm{~L}\end{array}$ & $\begin{array}{l}2 \\
2 \\
2\end{array}$ & $\begin{array}{l}1 \\
3 \\
7\end{array}$ & $\begin{array}{r}0.05 \\
0.03 \\
<0.01\end{array}$ & $\begin{array}{l}0.08 \\
0.06 \\
0.02\end{array}$ \\
\hline Strawberry & Nara & $\begin{array}{l}10 \% \mathrm{WP} \\
\times 2000 \\
150+150 \mathrm{~L}\end{array}$ & $\begin{array}{l}2 \\
2 \\
2\end{array}$ & $\begin{array}{l}1 \\
3 \\
6\end{array}$ & $\begin{array}{l}0.37 \\
0.44 \\
0.25\end{array}$ & $\begin{array}{l}0.40 \\
0.41 \\
0.27\end{array}$ \\
\hline Green pepper & Ibaraki & $\begin{array}{l}5 \% \mathrm{EC} \\
\times 1000 \\
300+300 \mathrm{~L}\end{array}$ & $\begin{array}{l}2 \\
2 \\
2\end{array}$ & $\begin{array}{l}1 \\
3 \\
7\end{array}$ & $\begin{array}{l}0.38 \\
0.32 \\
0.07\end{array}$ & $\begin{array}{l}0.40 \\
0.32 \\
0.09\end{array}$ \\
\hline Grape & Nara & $\begin{array}{l}10 \% \mathrm{WP} \\
\times 2000 \\
300 \mathrm{~L}\end{array}$ & $\begin{array}{l}1 \\
1 \\
1\end{array}$ & $\begin{array}{r}1 \\
7 \\
14\end{array}$ & $\begin{array}{l}0.34 \\
0.36 \\
0.24\end{array}$ & $\begin{array}{l}0.34 \\
0.40 \\
0.27\end{array}$ \\
\hline \multicolumn{7}{|c|}{ Satsuma mandarin } \\
\hline (peel) & Aichi & $\begin{array}{l}10 \% \mathrm{WP} \\
\times 2000\end{array}$ & $\begin{array}{l}1 \\
1 \\
1\end{array}$ & $\begin{array}{r}7 \\
14 \\
30\end{array}$ & $\begin{array}{l}1.21 \\
0.82 \\
0.64\end{array}$ & $\begin{array}{l}1.06 \\
0.78 \\
0.69\end{array}$ \\
\hline (pulp) & & $500 \mathrm{~L}$ & $\begin{array}{l}1 \\
1 \\
1\end{array}$ & $\begin{array}{r}7 \\
14 \\
30\end{array}$ & $\begin{array}{l}<0.01 \\
<0.01 \\
<0.01\end{array}$ & $\begin{array}{l}<0.01 \\
<0.01 \\
<0.01\end{array}$ \\
\hline \multicolumn{7}{|c|}{ Summer orange } \\
\hline (peel) & Kumamoto & $\begin{array}{l}10 \% \mathrm{WP} \\
\times 2000\end{array}$ & $\begin{array}{l}1 \\
1 \\
1\end{array}$ & $\begin{array}{r}7 \\
14 \\
30\end{array}$ & $\begin{array}{l}0.36 \\
0.18 \\
0.16\end{array}$ & $\begin{array}{l}0.40 \\
0.18 \\
0.16\end{array}$ \\
\hline (pulp) & & $500 \mathrm{~L}$ & $\begin{array}{l}1 \\
1 \\
1\end{array}$ & $\begin{array}{r}7 \\
14 \\
30\end{array}$ & $\begin{array}{l}<0.01 \\
<0.01 \\
<0.01\end{array}$ & $\begin{array}{l}<0.01 \\
<0.01 \\
<0.01\end{array}$ \\
\hline \multicolumn{7}{|l|}{ Peach } \\
\hline (peel) & Yamagata & $\begin{array}{l}10 \% \mathrm{WP} \\
\times 2000\end{array}$ & $\begin{array}{l}1 \\
1\end{array}$ & $\begin{array}{r}7 \\
14\end{array}$ & $\begin{array}{l}0.94 \\
0.30\end{array}$ & $\begin{array}{l}0.94 \\
0.28\end{array}$ \\
\hline (pulp) & & $300 \mathrm{~L}$ & $\begin{array}{l}1 \\
1\end{array}$ & $\begin{array}{r}7 \\
14\end{array}$ & $\begin{array}{l}<0.01 \\
<0.01\end{array}$ & $\begin{array}{l}<0.01 \\
<0.01\end{array}$ \\
\hline Green tea & Kochi & $\begin{array}{l}5 \% \mathrm{EC} \\
\times 1000 \\
400 \mathrm{~L}\end{array}$ & $\begin{array}{l}1 \\
1 \\
1\end{array}$ & $\begin{array}{r}7 \\
14 \\
21\end{array}$ & $\begin{array}{c}11.2 \\
4.2 \\
0.68\end{array}$ & $\begin{array}{c}10.4 \\
4.4 \\
0.76\end{array}$ \\
\hline
\end{tabular}

a) Average of duplicate analyses.

b) Expressed as HTZ.

cy-OH の抱合体も少量検出された ${ }^{2)}$. PT-cy-OH はシク ロへキサン環の 2 または $3 ， 4$ 位の水酸化体であり， 2 位， 3 位のものはそれぞれ 4 個の立体異性体を，4位の ものは 2 個の立体異性体を有し, 合計 10 個の異性体が 存在することになる．また，PT-cy-O にも合計 5 個の異 性体が存在する．これらすべての代謝物を個別に定量す るのは，きわめて困難と考元られたので，HTZ および 代謝物を一つの化合物に統一する全分析法について検討 した結果, アルカリ溶液中での加水分解により PT-1-3 に統一できることがわかったので,この方法を採用した.
植物代謝実験や加水分解実験の結果から, PT-1-3 よりも さらに分解が進んだ代謝物はきわめて少ないことが十分 に予想されたので，それらは残留分析の対象には入れな かった.

定量法として紫外吸光光度法, 高速液体クロマトグラ フ法拉よびガスクロマトグラフ法の 3 法が考光られた. 紫外吸収スペクトル法や微分スペクトル法は簡便である が，極大吸収波長は HTZ. および PT-1-3 はともにアセ トニトリル溶液中で短波長領域（225 nm 付近）にあり, 生体成分の妨害を受けやすかったので採用しなかった。 
しかし紫外線検出器付 HPLC を用いることにより,HTZ 分析法抒よび全分析法を作成することができた，GCで HPLC と同程度の検出限界を維持して HTZ 定量をする ためには，PEG-HT/Uniport HP を充填剤として用いる 必要があった. 全分析法の場合は, PT-1-3 に变換後, ガ スクロマトグラフに注入するので，上記の充塡剂のほか に DC-200/Uniport HP, SE-30/Chromosorb W 等の使用 も可能であったが，HPLC 法と同等に検出下限を 0.01 ppm にするためには，現在のところ FTD と PEG-HT/ Uniport HP の組合せのみが有効であった，さらに，GC で全分析法により分析を行なうと，作物によっては HPLC を用いる時よりも分析操作が長くなった。 これら の結果より, 現時点では HPLC による分析が最良と考 えられた。

クリンアップとして HTZ 法の場合は，アセトニトリ ルーヘキサンの分配と通常のフロリジルカラムクロマト グラフィーで十分であったが，全分析法ではメタノール 抽出液あるいはアセトン抽出液からジクロロメタンに HTZ および代謝物を転溶しているので, 転溶溶媒として へキサンを用いる HTZ 分析法より作物由来の妨害成分 が多く抽出された。 茶中のタンニン類の除去や, 相橘類 果皮由来の妨害成分は液液分配や通常のカラムクロマト グラフィーのみのクリンフップでは不十分であった．こ れら妨害成分除去のために酶酸鉛や水酸化カルシウムに よる凝固法を検討したが，除去効果が不十分であったり HTZ が吸着されて良好な結果が得られなかった。 そこ で, 逆相系のパックドカラムによりクリンアップを試み た結果, 非常に有効であった. 作物によっては順相系 (吸着型) パックドカラムも有効に用いることができた。 ミカン果皮を全分析法で分析する場合，順相系のパック ドカラムを用いるととにより前記分析法中に示したカラ ムクロマトグラフィーおよび逆相系のパックドカラムを 用いる必要もなく，HPLCによる定量が可能であった。 しかし, ナッミカン, 茶, キュウリ等ではクリンアップ 効果が十分でなかったので最終的には採用しなかった. 加水分解の最適条件はメタノール $5 \mathrm{ml}$ で残留物をよく 溶解し, $0.01 \mathrm{~N}$ 水酸化ナトリウム $50 \mathrm{ml}$ を加え 20 分間, 加熱還流することであった．この条件で HTZ および代 謝物は定量的に PT-1-3 に变換し,生成した PT-1-3 はま ったく安定であった. しかし, 茶のように妨害物が多量 に含まれる場合は，この条件では PT-1-3への変換が不 十分であったため， $0.02 \mathrm{~N}$ 水酸化ナトリウムを用いる ことにより，満足できる変換率を得た。しかし，0.1 N 水酸化ナトリウム溶液を用いると生成した PT-1-3 の安 定性が悪くなった.
HTZ 法と全分析法で，リンゴ，キュウリ，イチゴ， ミカン, ナッミカン, モモ, ピーマン, ブドウ, および 茶について残留分析を行なった結果, 両分析法による分 析値にほとんど差は認められなかった。 また，両分析法 による添加回収率にも大きな差はなかった。これらのこ とより，固場でニッソラン水和剤や乳剂を散布し収穫し た作物中に拈ける残留物はほとんどが HTZ と考えら れ，PT-1-2, PT-cy-OH, PT-cy-O や PT-cy-OH の抱合 体は，たとえ存在しても，きわめてわずかであることが わかり, 植物代謝研究の結果とよく一致した. 以上より 安全性評価を目的とした残留分析を実施する場合，HTZ 法は迅速，簡便であり，しかも現在の国内基準である分 析精度 $(10 \%$ 以内), 回収率 ( $70 \%$ 以上), 検出限界 $(0.05$ ppm 以下）とも満足しているので, 最適の方法であると 考えられる.

また, 作物中の HTZ は, 作物を有姿状態のままでー30 ${ }^{\circ} \mathrm{C}$ で保存すれば，少なくとも 1 年間は安定であった。

\section{要約}

HTZ 分析法と代謝物をも対象とした全分析法を検討 し，それぞれ十分実用性のある HPLC 法を作成するこ とができた. HTZ 法はメタノール抽出液を液液分配, 力 ラムクロマトグラフィーで精製後, HPLC で定量した. 全分析法は HTZ 法と同様にメタノール抽出液を液液分 配後, HTZ 拉よび代謝物を加水分解して PT-1-3 に变換 し, カラムクロマトグラフィー等で精製後, HPLC で定 量する方法を作成した。両分析法ともに試料科取量が $50 \mathrm{~g}$ の時, 検出限界法 $0.01 \mathrm{ppm}$, 回収率 $80 \%$ 以上, 変 動俰数 2 3\% であった. HPLCを用いて HTZ 法打よ び全分析法で 9 作物（12 作物部位）の分析を行なった結 果, 残留值にほとえぞ差は認められなかった。 このこと から HTZ 処理した作物に残留している化合物は大部 分 HTZ であることがわかったので，作物残留実態を調 べるには迅速，簡便な HTZ 分析法が最適であると考兄 られた。

本研究に協力していただいた日本曹達株式会社二本木 工場の川上 肇氏抒よび当研究所の添田吉則博士および 杉岡克己氏他残留分析担当者の方々に深く感謝いたしま す.

\section{引 用 文 献}

1）橋本恭明・石原莞爾・杉本茂二・添田吉則：日本 農薬学会第 11 回大会講演要旨集, p. 100, 1986

2）中島信一・橋本恭明 - 添田吉則: 日本農薬学会第 12 回大会講演要旨集, p. 134, 1987 